\title{
Editor's Foreword
}

This special issue of the journal Asian studies is dedicated to the Sinicization of Marxism as a paradigm for research on Marxist philosophy in contemporary China. There are several reasons for choosing this topic, and are by no means limited to the fact that just a few months ago, on May 5th 2018, we celebrated Karl Marx's bicentenary. As far as Marx in our time is concerned, my impression is that over these two centuries he was maturing, a bit like a noble cheese or a vintage wine not appropriate for Dionysian parties or guzzling at the firing lines. Rather, he is a stimulating companion for profound thought about the meanings of modernity and especially of human emancipation, an issue which remains of significance for the contemporary world.

The topic itself stimulates our interest, for, as we all know, a great many curious things have befallen Marxism as an intellectual and political tradition, and its adoption by the revolutionary forces under the leadership of Mao Zedong was by no means the least of them. So, how did the Long March of Sinicizing Marxism began?

Although the wide influence of Marxism can be traced back to September 15, 1915 , i.e. the date of the foundation of the leading progressive magazine Xin Qingnian (新青年) or The Nerw Youth, serious discussion by Chinese intellectuals of Marxist dialectics and historical materialism, did not start until after the Russian Revolution of 1917. As Tian Chenshan, who is one of the crucial authors of this issue, has pointed out, the introduction of Marxist dialectics into China can be divided into three periods. First, between 1917 and 1927, there were discussions of historical materialism, particularly after the publication of essays on historical materialism in the special issue of the famous journal The New Youth in 1919. Second, between 1926 and 1937, there were discussions of Russian writings on dialectical materialism starting with Qu Qiubai's lectures in Shanghai. This period saw the campaign to popularize the concept of dialectics, headed by leading communist theoreticians like Ai Siqi. The third period began after 1937 with Mao Zedong's idea of the Sinicization of Marxism (马克思主义的中国化) and his essays On Contradictions (矛盾论) and On Practice (实践论).

The Yan'an period, especially the year 1937, in which Mao wrote these two famous essays, is widely regarded as the actual beginning of the Sinicization of Marxism. The current emphasis on Mao's pre-Liberation contributions to Marxist theory makes it appropriate and relevant to raise for discussion the distinctive manner in which Mao addressed this problem of integrating the universal theory of Marxism 
with the "concrete practice" of Chinese society and the Chinese revolution. One of the main goals of this issue is also to address the question of how the ideological debates and Marxist prescriptions that shaped the historiography of Chinese philosophy from the late 1950s of the Mao era still provide a background for the contemporary period.

Mao's proposal for the "Sinicization of Marxism" remains one of the most intriguing issues in the ideological history of the Chinese Communist Party (CCP). Strangely, although this concept is given passing treatment in numerous studies of the Chinese Communist movement, little attempt has been made to subject it to a more detailed historical or theoretical analysis. Hence, it is also the purpose of this issue to analyze the form, contents and wide reaching influences of this Sinicization of Marxism at Mao's hands. Broadly, the concept contains several interrelated, though distinct, dimensions. Hence, we aim to illuminate it proceeding from several different perspectives.

The content of the present issue is thus divided into four scopes. The first one is entitled Hegel, Marx and Traditional Chinese Dialectics and mainly deals with theoretical and methodological foundations of the Sinicization process. It includes four articles, which elaborate on several crucial questions linked to culturally determined differences in dialectical thought and the fate of the Hegelian heritage in the Chinese theory. Tian Chenshan, the author of the first article, entitled Mao Zedong, Sinicization of Marxism, and Traditional Chinese Thought Culture, argues that due to the fact that the Chinese tradition also created a model of dynamic dialectical thought, certain of Marx's cosmological assumptions were better understood by the Chinese intellectuals and were more suitable for Sinicization than many other theories. The second paper, Fabian Heubel's Beyond Murderous Dialectics: On Paradoxical Thinking and Maoism, deals with the contradiction between Marxist foundations of the current "socialism with Chinese characteristics" on the one side and the renaissance of traditional culture and classical learning on the other, proceeding from the assumption that the power of Mao Zedong's thought derived from its capability to systematically subordinate the transformative philosophy of Chinese tradition to the Marxist model of class struggle. Hegel and Chinese Marxism is the title of the third article in this scope. Its author, Tom Rockmore, explores in this contribution the relation between this German philosopher and Sinicized Marxism from the viewpoint of $\mathrm{Xi}$ Jinping's notion of the "Chinese dream." The author of the last paper in this scope is Ozan Altan Altinok. In his contribution, entitled Mao's Marxist Negation of Marxism: The Limits of Revolutionary Subject's Negation of Revolutionary Theory without Affirming Itself, he analyzes Mao Zedong's conception and application of Marxism in some of Mao's own works. 
The second scope explores the relation between Marxism and the Chinese, particularly the Confucian ideational tradition. While Téa Sernelj's paper Modern Confucians Objection against Communism in China: The Unique Case of Xu Fuguan critically introduces the relation between the Modern New Confucian movement and the Maoist communism, Andrej Ule deals with the question of harmony in a similar context. In his paper Harmony as an Ethical and Political Idea: he investigates the possibilities of achieving genuine harmony as a part of solidarity based on the reciprocal and universal cultivation of personal dignity and virtuous humaneness. The third article in this scope, Bart Dessein's Guo Moruo on Marx and Confucius analyses how Guo Moruo, despite being a self-declared Marxist, kept on adhering to some Confucian principles. Through his analysis, Dessein finds some additional explanations for the fact that, after having been criticized in the early seventies of the 20th century, Guo is now, within the revival of Confucianism, being once again reevaluated again.

The next scope of contents deals with the theories and ideologies of Sinicized Marxism. In his paper Marxist Theories of Ideology in Contemporary China: The Pioneering Work of $\mathrm{Yu}$ Wujin, Adrian Krawczyk explores the contemporary application and many topical connotations of the notion of ideology, which is one of the central terms of Marxist theory. The second paper in this scope is entitled From Religion to Revolution... and Nationalism: Hui Identity and Historical Materialism in the Work of Jamāl al-Din Bai Shouyi and Beyond, and written by Ady van den Stock. In this article, the author explores the relation between national identity and Marxist political theory through the lens of Islamic philosophy. In her contribution Li Zehou and His Rocky Relationship with Marx: Class Struggle as a Form of Kantian Transcendental Illusion, Jana S. Rošker introduces Marxist and Kantian elements in the theory of the contemporary Chinese philosopher Li Zehou.

The last scope includes three papers from the fields of history and social sciences. The first article in this scope, On the Transformations of PRC Academic Philosophy: Maoist Features and Their Use under Xi Jinping, was written by Yvonne Schultz-Zinda, who compares the Maoist features during the transformative period in the 1950s and that under Xi Jinping's contemporary politics. Marko Hočevar's paper Mao's Conception of the Revolutionary Subject: A Socio-bistorical Approach on the other hand, illuminates the multifaceted relations between different classes, focusing upon the one that marks the complex connections between the peasantry and the proletariat. Last but not least, the scope (and the entire special issue) concludes with the paper Equ(al)ity and Community in China after 40 Years of Economic Reforms: Sinicised Marxism and "Socialism with Chinese Characteristics" in Crisis. In this article, its authors Alessia A. Amighini and Peitao Jia illuminate how Sinicized Marxism accentuated Marx's philosophy of 
history, rather than any version of Marxist egalitarian political philosophy, concluding that it has, through such an approach, developed a culturally distinctive version of Marxism as an authoritarian (rather than democratic) discourse.

Through the lens of these multifarious approaches, this special issue clearly shows that in its political aspects the notion of Sino-Marxism refers to the specific, often highly problematic ways in which the "foreign" theory of Marxism-Leninism could be adapted to the concrete historical realities of modern China, including the under-development of capitalism, the absence of a large urban proletariat, the central role of the rural peasantry, and so forth. These are difficult problems of political theory, and they have not yet been resolved satisfactorily either in Chinese or Western scholarship. Whether Marxism has been truly Sinicized in this sense--and whether it has survived the process intact--are highly controversial issues, and we hope that some of them could be illuminated, if not clarified in this volume.

All this points to the fact that the idea of the Sinification of Marxism has a distinctly cultural side to it. In its cultural dimension, it refers primarily to the problem of reconciling a foreign ideological doctrine with the distinctive cultural character of China. Hence, another important dimension of this volume regards the ideological role of the Chinese cultural tradition in the process of Sinicization of Marxism. In this respect, it is important to proceed from the contemporary situation and to show why and in which way the present, ideologically modified Confucianism, along with the so-called "traditional culture," were implemented as a new symbolic capital into the discourse of the new Chinese nationalism. It is also important to reveal that such a modified tradition remained effective insofar as those struggling for ideological legitimacy remain silent about the Chinese revolutionary legacy and ideology, namely socialism and Marxism. But this is problematic, for no one can cancel out in one stroke China's revolutionary past. The ideologized version of Confucianism, on the other hand, can neither truly serve as an indigenous thought legitimizing a new national autonomy, because contemporary Confucian discourse itself is being constituted globally as an integral part of the ideology of capitalist globalization. At the most, it can reflect a radical metamorphosis of nationalism from a discourse of resistance to a discourse of domination. When Immanuel Wallerstein speaks of "nationalism as domination," (1974) he is primarily concerned with "those more frequent moments when nationalism operates ... as the nervous tic of capitalism as a world-system." In the case of China, the transition from resistance to domination is a precarious one, and it is based upon the suppression of a powerful revolutionary legacy. On the other hand, however, the current leadership by no means surrenders itself entirely 
to the capitalist world-system, as shown by the persistence of the slogan, however empty and self-contradictory in its content, Socialism with Chinese Characteristics. All this generates a profound uneasiness with the "official" nationalism, which is, at first glimpse, Confucian oriented. Hence, several authors of the papers included in this special issue attempted to purify Confucianism from its recent ideological and nationalist connotations in order to make room for a more objective and academically more reliable discussion on certain traditional notions that can shed additional light to the process of integrating the Chinese intellectual tradition into the scope of Marxist theories. We hope that such an intercultural dimension of theoretical exchanges can-inter alia-serve as a first step in the search for a better understanding of recent history and its multifarious ideational heritages.

(c) (1) ()

Jana S. Rošker, Chief Editor 